\title{
Before and after: millet cultivation and the transformation of prehistoric crop production in northern Germany
}

Dragana Filipović ${ }^{1, *}$, John Meadows ${ }^{2}$, Julian Wiethold ${ }^{3}$, Susanne Jahns ${ }^{4}$, Felix Bittmann ${ }^{5} \&$ Wiebke Kirleis ${ }^{1}$

A programme of radiocarbon dating aims to correlate the onset of millet cultivation in northern Germany with cultural and technological changes during the Bronze Age.

Keywords: Germany, Bronze Age, millet, radiocarbon dating

\section{Research questions and expectations}

Broomcorn millet (Panicum miliaceum L.) is thought to have been introduced into Europe from Asia as early as the Neolithic period, although this has recently been challenged (see Motuzaite-Matuzeviciute et al. 2013). It had most probably become a cultivated crop by the Middle or Late Bronze Age (Stika \& Heiss 2013), as its significant presence-often in the form of large deposits of grains - has been observed at some Bronze Age sites (Figure 1). Furthermore, isotopic and biomolecular evidence from this period suggests the preparation and consumption of food that included millet (e.g. Lightfoot et al. 2013; Heron et al. 2016).

Innovations need time to spread and become established. Once millet had arrived in Europe, it may have taken time to recognise its potential and incorporate it into the existing annual crop-production cycle. A new crop, however, could be adopted quickly, if the social, economic and agricultural requirements were favourable (Thirsk 1985: 542). Which, if either, of these two scenarios is applicable to the arrival and diffusion of millet in and across Northern Europe?

We will address this question through AMS radiocarbon dating of broomcorn millet grains recovered from Neolithic and Bronze Age sites in northern Germany

1 Institute for Pre-and Protohistory, Christian-Albrechts-University Kiel, Johanna-Mestorf-Strasse 2-4, D-24118 Kiel, Germany

2 Centre for Baltic and Scandinavian Archaeology, Schleswig-Holstein State Museums Foundation, Schloss Gottorf, D-24837 Schleswig, Germany

3 Institut National de Recherches Archéologiques Preventives, Direction Régionale Grand-Est, Laboratoire Archéobotanique, 12 Rue de Méric, CS 80005 F-57063 Metz Cedex 2, France

4 Brandenburgisches Landesamt für Denkmalpflege und Archäologisches Landesmuseum Ortsteil Wünsdorf, Wünsdorfer Platz 4-5, D-15806 Zossen, Germany

5 Lower Saxony Institute for Historical Coastal Research, Viktoria Strasse 26/28, D-26382 Wilhelmshaven, Germany

* Author for correspondence (Email: d.filipovic@ufg.uni-kiel.de)

(c) Antiquity Publications Ltd, 2018

ANTIQUITY 92 365, e3 (2018): 1-6

https://doi.org/10.15184/aqy.2018.225 


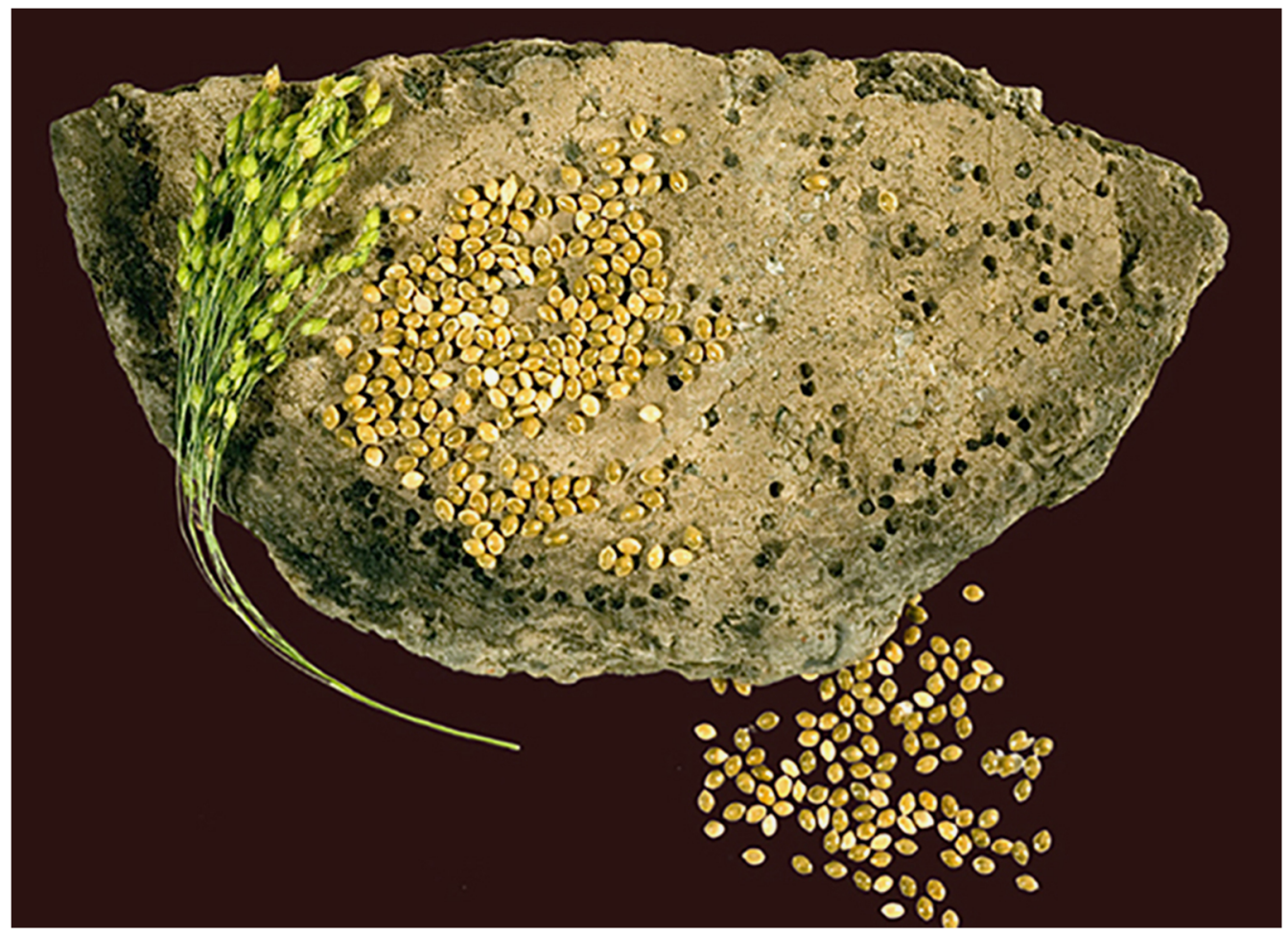

Figure 1. Modern broomcorn millet plant and grains, and a potsherd from the Late Bronze Age site of Bruszczewo, Poland, showing imprints of millet grains (photograph courtesy of S. Jagiolla, UFG Kiel).

(Figure 2 \& Table 1). We expect these analyses to identify the earliest presence of millet in this part of the world, to estimate the 'start date' of millet cultivation based on the precise age of large millet deposits and to recognise potential intra-regional differences. The targeted material includes both small occurrences of millet (1-2 grains per deposit) and 'mass' (highdensity) finds. The dating is being performed at the radiocarbon laboratories in Poznan and Kiel following standard protocols (i.e. there is no modification in pre-treatment to account for small grain size, unlike Motuzaite-Matuzeviciute et al. 2013). As a strict rule, single grains are dated.

\section{Initial results and ways forward}

Until now, AMS dates on single millet grains from seven Neolithic and/or Bronze Age sites have been obtained (Figure 3). Results suggest that it is unlikely that millet appeared much before $1200 \mathrm{cal} \mathrm{BC}$ - the very beginning of the Late Bronze Age in Germany. The earliest date, for now, is from the mass find of millet from Rullstorf (Figure 4); this may represent the earliest example of millet cultivation in the region (Kirleis 2003). The majority of the dates are from grains deriving from small millet deposits. If deposit size is taken as reflecting the crop or no-crop status of millet, it seems as though millet was cultivated at some sites by or at

(C) Antiquity Publications Ltd, 2018 


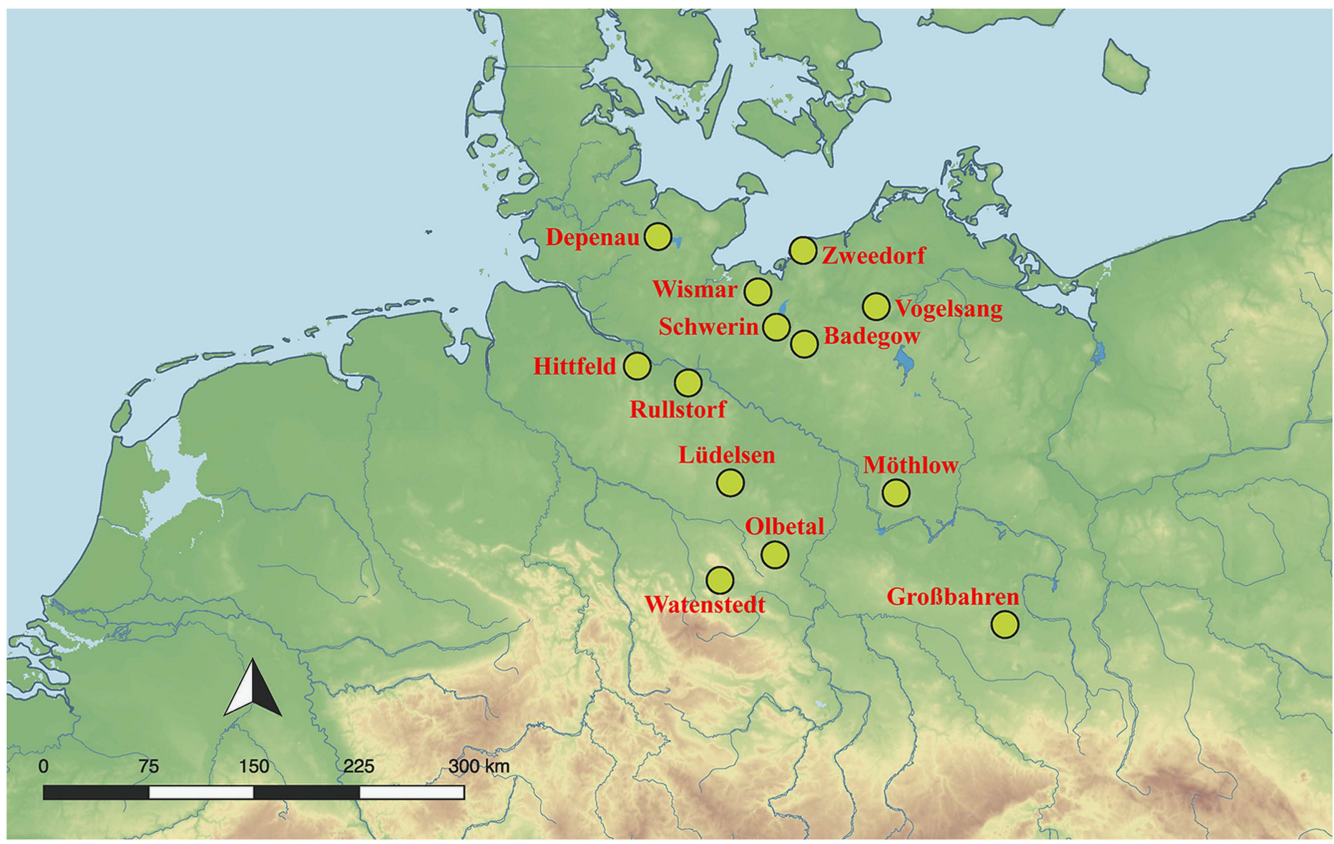

Figure 2. Map showing the location of the sites that produced millet grains for dating (figure by D. Filipovic').

Table 1. Northern German sites from which millet grains have been dated

\begin{tabular}{|c|c|c|c|}
\hline $\begin{array}{l}\text { Region in } \\
\text { northern } \\
\text { Germany }\end{array}$ & Site & $\begin{array}{l}\text { Size of millet-containing } \\
\text { deposit }\end{array}$ & Number of grains dated \\
\hline \multirow[t]{3}{*}{ Brandenburg } & Potsdam-Satzkorn & Small (single grain) & Single grain \\
\hline & Großbaren & Large (hundreds of grains) & Single grain \\
\hline & Möthlow & $\begin{array}{l}\text { Small (approximately two } \\
\text { dozen grains) }\end{array}$ & Single grain \\
\hline \multirow[t]{2}{*}{ Hamburg } & Hittfeld & Small (five grains) & Single grain \\
\hline & Watenstedt & Large (thousands of grains) & Two single grains \\
\hline Lower Saxony & Rullstorf & Large (thousands of grains) & $\begin{array}{l}\text { Approximately } 0.5 \mathrm{~g} \text { of grains combined } \\
\text { (dated previously); clump of } \\
\text { approximately } 20 \text { grains combined }\end{array}$ \\
\hline \multirow{5}{*}{$\begin{array}{l}\text { Mecklenburg- } \\
\text { Vorpommern }\end{array}$} & Zweedorf & Small (two grains) & Single grain \\
\hline & Vogelsang & Small (single grain) & Two single grains, from two features \\
\hline & Schwerin & Small (single grain) & Single grain \\
\hline & Badegow & $\begin{array}{l}\text { Large (approximately } 100 \\
\text { grains) }\end{array}$ & Single grain \\
\hline & Wismar & Large (thousands of grains) & Two single grains \\
\hline \multirow[t]{2}{*}{ Saxony-Anhalt } & Olbetal & Small (1-2 grains) & Five single grains \\
\hline & Lüdelsen LA6 & Small (several grains) & Two grains combined (dated previously) \\
\hline Schleswig-Holstein & Depenau LA17 & Small (two grains) & Single grain \\
\hline
\end{tabular}




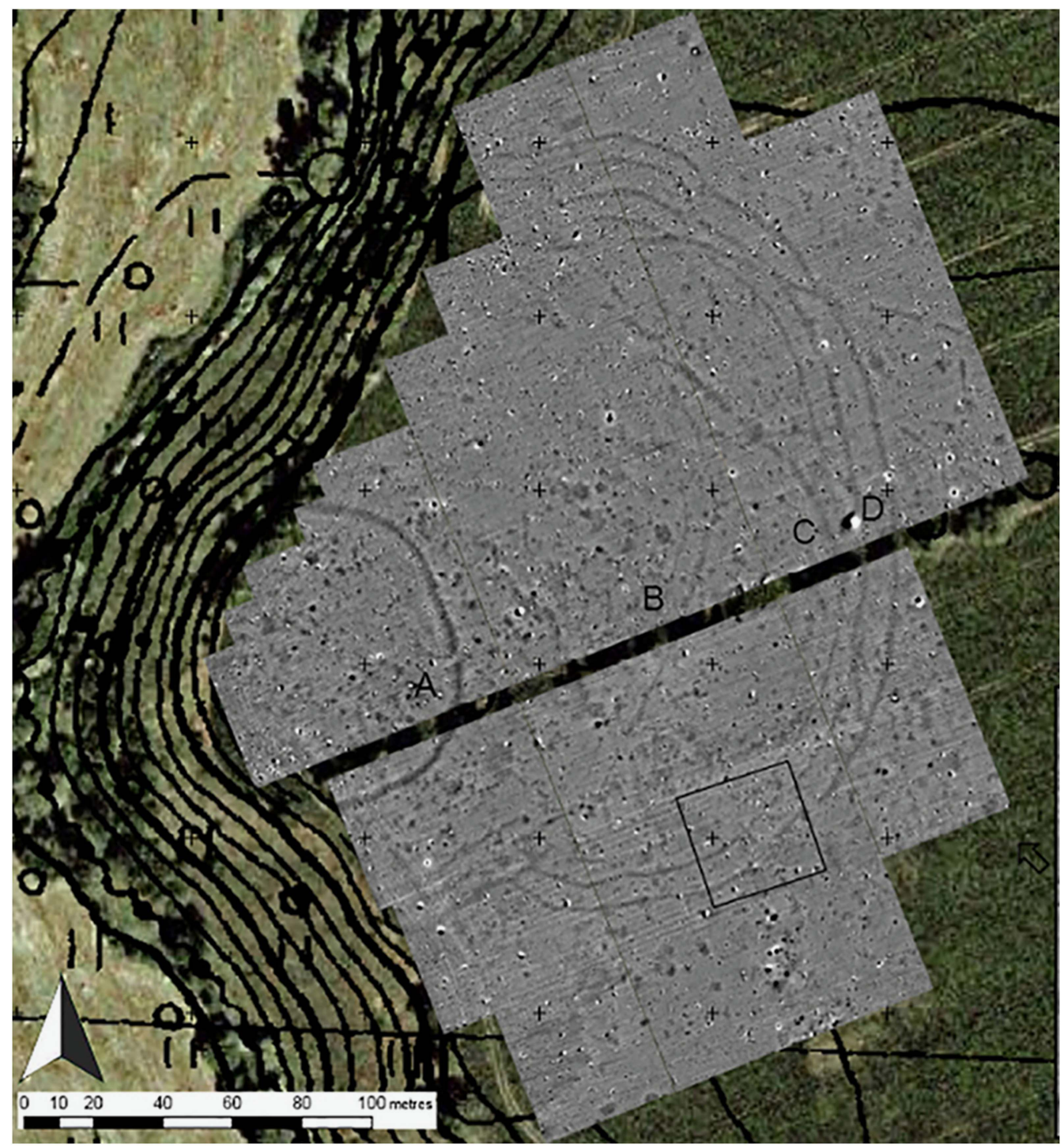

Figure 3. The site of Olbetal, with Neolithic (large, triple ditch) and Bronze Age (small, single ditch) enclosures; millet grains found in both derive from the mid Late Bronze Age (photograph courtesy of C. Rinne, UFG Kiel).

the start of the Late Bronze Age, but not at others. Thus, there may not have been a general adoption of millet cultivation across the region.

As broomcorn millet is a short-season plant, its sowing and harvest can take place within the summer months. Well adapted to a range of soils and climatic conditions, it is drought and heat resistant, and can grow at high or low altitudes (e.g. Miller et al. 2016). Archaeobotanical data suggest that the cultivation of several other species, including spelt wheat (Triticum spelta L.), gold of pleasure (Camelina sativa (L.) Crantz) and faba beans (Vicia faba L.), probably began in northern Germany in the Late Bronze Age (Effenberger 2018). In this period also, weed species became more abundant and diverse across the study (C) Antiquity Publications Ltd, 2018 


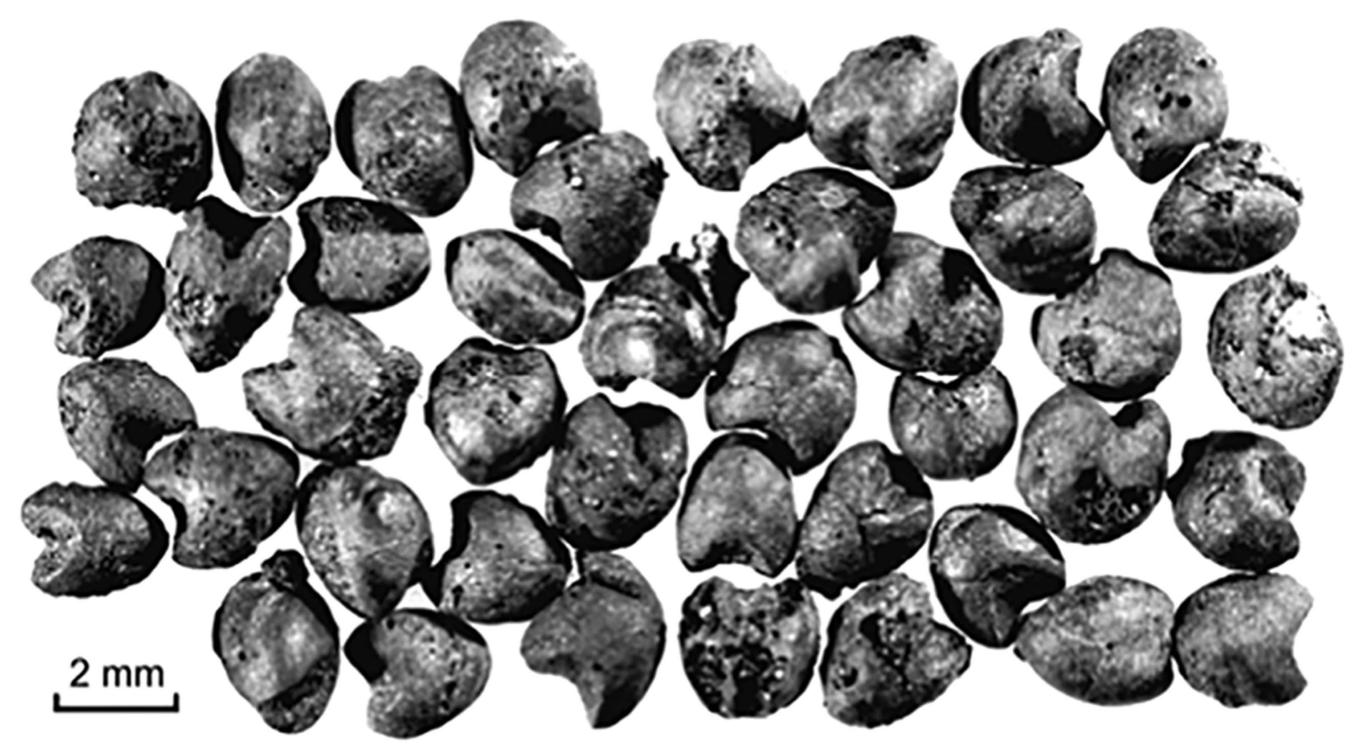

Figure 4. Charred broomcorn millet grains from Rullstorf (photograph courtesy of W. Kirleis, UFG Kiel).

region (Effenberger 2017). This development perhaps pertains to the addition of millet (and other 'new' crops) to the former (Neolithic) crop suite. It may reflect changes in agricultural practice, such as a shift to more extensive agriculture, increased variability in cultivation intensity (e.g. infield-outfield farming; Christiansen 1978), and/or cropping in newly established arable areas, such as those that were waterlogged in winter and only available for summer crops (e.g. millet).

\section{Acknowledgements}

The millet dating programme is part of the 'Dynamics of Plant Economies in Ancient Societies' project carried out at the Institute for Pre- and Protohistory of the University of Kiel, within the Collaborative Research Centre 1266 'Scales of Transformation', and is funded by the German Research Foundation. Dating is being performed at the Poznań Radiocarbon Laboratory, Adam Mickiewicz University and the Leibniz-Laboratory for AMS Dating and Stable Isotope Research, Christian-Albrechts-University, Kiel.

\section{References}

Christiansen, S. 1978. Infield-outfield systemscharacteristics and development in different climatic environments. Geografisk Tidsskrift 77: $1-5$.

https://doi.org/10.1080/ 00167223.1978 .10649086

Effenberger, H. 2017. Pflanzennutzung und Ausbreitungswege von Innovationen im Pflanzenbau der Nordischen Bronzezeit und angrenzender Regionen (Studien zur nordeuropäischen Bronzezeit 4). Neumünster: Wachholtz.
- 2018. The plant economy of the Northern

European Bronze Age-more diversity through increased trade with adjacent cultures. Vegetation History and Archaeobotany 27: 65-74.

https://doi.org/10.1007/s00334-017-0621-3

Heron, C., S. Shoda, A.B. Barcons, J. Czebreszuk, Y. Eley, M. Gorton, W. Kirleis, J. Kneisel, A. Lucquin, J. Müller, Y. Nishida, J. Son \& O.E. Craig. 2016. First molecular and isotopic evidence of millet processing in prehistoric pottery vessels. Scientific Reports 6: 38767. https://doi.org/10.1038/srep38767

(C) Antiquity Publications Ltd, 2018 
KIRLEIS, W. 2003. Vegetationsgeschichtliche und archäobotanische Untersuchungen zur Landwirtschaft und Umwelt im Bereich der prähistorischen Siedlungen bei Rullstorf, Ldkr. Lüneburg. Probleme der Küstenforschung im südlichen Nordseegebiet 28: 65-132.

Lightfoot, E., X. Liu \& M.K. Jones. 2013. Why move starchy cereals? A review of the isotopic evidence for prehistoric millet consumption across Eurasia. World Archaeology 45: 574-623. https://doi.org/10.1080/00438243.2013.852070 Miller, N.F., R.N. Spengler \& M. Frachetti. 2016. Millet cultivation across Eurasia: origins, spread, and the influence of seasonal climate. The Holocene 26: 1566-75. https://doi.org/10.1177/0959683616641742
Motuzaite-Matuzeviciute, G., R. Staff, H.V. Hunt, X. Liu \& M.K. Jones. 2013. The early chronology of broomcorn millet (Panicum miliaceum) in Europe. Antiquity 87: 1073-85. https://doi.org/10.1017/S0003598X00049875

Stika, H.-P. \& A.G. Heiss. 2013. Plant cultivation in the Bronze Age, in H. Fokkens \& A. Harding (ed.) The Oxford handbook of the European Bronze Age: 348-69. Oxford: Oxford University Press.

THIRSK, J. 1985. The agrarian history of England and Wales. Cambridge: Cambridge University Press. 